\title{
Effect of different levels of dietary energy on growth and carcass traits of Black Bengal goat
}

\author{
ME Kabir ${ }^{1,3}$, MB Sarker ${ }^{1}$, BK Saha ${ }^{1}$, MAMY Khandoker ${ }^{2}$, M Moniruzzaman*1 \\ ${ }^{1}$ Department of Animal Science; ${ }^{2}$ Department of Animal Breeding and Genetics, Bangladesh Agricultural University, \\ Mymensigh 2202, Bangladesh; ${ }^{3}$ Department of General Animal Science and Animal Nutrition Patuakhali Science and \\ Technology University, Babugonj, Barisal 8210, Bangladesh
}

\begin{abstract}
The present study was aimed to know the effect of dietary energy levels on growth and carcass characteristics in Black Bengal goats. Nine female Black Bengal goats were divided into three groups having three goats in each group. Three iso-nitrogenous diets containing three levels of metabolizable energy $(9.17,10.40$ and $11.63 \mathrm{MJ} / \mathrm{kg} \mathrm{DM}$ ) were randomly assigned to three groups. Goats were stall fed and slaughtered after 150 days of trial. Results showed that live weight gain was higher $(28.3 \pm 1.7$ $\mathrm{g} /$ day) in high energy fed goats than others. There were no significant differences on total and daily average dry matter intake in different groups of goats. Body length was significantly higher in high energy fed group than others. Carcass weight and dressing percentage were also higher $(p<0.05)$ in high energy fed goats. Caul fat and gut fill weight differed significantly $(p<0.05)$ among the treatment groups, and higher caul fat and lower gut fill were obtained in high energy fed goats than others. In conclusion, high energy diet enhanced the growth, dressing percentage and carcass gain of female goats.
\end{abstract}

Key words: Carcass, dietary energy, goat, growth

Bangladesh Animal Husbandry Association. All rights reserved. Bang. J. Anim. Sci. 2011.43 (2): 159-165

\section{Introduction}

Goats play a potential role in the subsistence economy of Bangladesh. Goat population in Bangladesh constitutes nearly $11.79 \%$ of the total population in Asia (FAO 2010). It is estimated that more than $90 \%$ of the goat population in Bangladesh are Black Bengal goats which are widely distributed throughout Bangladesh (Husain et al. 1998). Goat production in Bangladesh are reputed due to their early maturity, high prolificacy, delicacy of meat, superior skin quality, disease resistance and wide range of acceptability under adverse agro climatic condition (Devendra and Burns 1983; Husain et al. 1998). The higher demand of meat and skin in the local as well as foreign markets focused the goat enterprise extremely prominent to the vulnerable group of people in the existing socioeconomic condition of the country (Husain 1993). Higher reproductive efficiency, better capacity to subsist on harsh nutritional regime and low risk of death make a viable proposition for increasing the productivity of goats.

Low energy intake is a major problem in goat production (McGregor 1984). Calhoun et al.
(1988) reported that the trend of increasing energy intake bears a positive propensity of increasing live weight gain in goats. Van der Westhusyen et al. (1985) suggested that adequate supply of energy and protein is essential to maintain normal body function like growth and reproduction. A high plane of nutrition has a significant effect on growth rate (Wilson 1958; Devendra 1988). Dietary nutrient especially energy is the major environmental factor affecting growth performance in goats (Ash and Norton 1987; Shahjalal et al. 1992).

In Bangladesh, goats are traditionally raised by "poverty-stricken" village people in a sedentary system of grazing on harvested fallow land, along the roads and canal sides without supplementation. This system of feeding can not satisfy their nutrient requirement for maintaining proper growth performance, resulting in severe economic losses. Effects of dietary energy levels on growth and carcass characteristics of Black Bengal goats are not known precisely. Therefore, the present experiment was designed to study the influence of dietary energy levels on growth 
performance, carcass and non-carcass parameters of Black Bengal goats.

\section{Materials and Methods}

The experiment was conducted with nine female Black Bengal goats of around 6 months. Their initial body weight ranged from 6 to $8 \mathrm{~kg}$. Before starting the experiment, they were allowed for four weeks to adjust themselves with the experimental conditions and diets. Goats were housed in well ventilated separate pens. In each pen, 3 goats were kept with 14.67 square feet per goat. Every day the floor, feeder and water trough were cleaned using phenyl as antiseptic. Separate feeder was used for roughage and concentrate feeding. Before starting the experiment goats were dewormed with anthelmentic drug (Dovenix, Advance Pharmaceuticals Company limited, Hong Kong) and vaccinated against the PPR (Peste des Petits Ruminants) disease.

Three diets were formulated using commonly available feed ingredients such as natural grass, wheat bran, maize, soybean meal, molasses, DCP (dicalcium phosphate) and common salt. The medium energy diet was formulated to contain 10.40 MJ ME/kg DM following NRC (1981). Other diets contained high energy, $\mathrm{HE}=11.63 \mathrm{MJME} / \mathrm{kg}$ $D M$ and low energy, $L E=9.17 \mathrm{MJME} / \mathrm{kg} \mathrm{DM}$. All diets were iso-nitrogenous containing $14 \%$ crude protein per $\mathrm{kg}$ DM. The ingredients and their chemical composition are presented in Table 1.

Table 1. Ingredients and chemical composition of the experimental diets (DM basis)

\begin{tabular}{lccc}
\hline \multicolumn{1}{c}{ Items } & \multicolumn{3}{c}{ Energy Levels } \\
\hline \multicolumn{1}{c}{ Low } & Medium & High \\
\hline Ingredients (\%) & 60 & 60 & 48 \\
Natural grass & 33.7 & 13.5 & 2 \\
Wheat bran & 0.5 & 15.7 & 36 \\
Maize & 5 & 8 & 10 \\
Soybean meal & - & 2 & 3 \\
Molasses & 0.4 & 0.4 & 0.5 \\
Common salt & 0.4 & 0.4 & 0.5 \\
DCP & & & \\
Chemical Composition & 9.17 & 10.41 & 11.64 \\
ME* (MJ/kg DM) & 14 & 14 & 14 \\
CP* $\%$ ) & & & \\
\hline
\end{tabular}

*ME and CP values were estimated following Banerjee (1978)
All the goats were stall fed. Diets were adjusted for required nutrient on the basis of live weight change of the animals in various treatments at the end of every fifteen days. The concentrate mixture was supplied first and then green grass was fed. The ration was supplied in two equal parts in the morning and evening. Fresh drinking water was supplied in bucket at all time for ad libitum drinking. Every morning and evening before feeding the animals, each feed was weighed carefully and total quantity of feed supplied to animals was recorded. Before supplying feed to the animals, the amount of refusals of feeds of the previous day was collected, weighed and recorded. The feed refused by each individual animal during $24 \mathrm{hrs}$ was deducted from the feed supplied to the animals and recorded as the daily feed intake by the animal.

Goats were weighed individually at fortnightly by using electric balance. Weighing was performed at 8.30 AM before offering feed. Live weight, length of body, heart girth, circumference and length of neck, and height at wither of each goat were recorded prior to slaughter. Before slaughtering, goats were fasted overnight. Goats were slaughtered following the "Halal" method. By this method goats were bled by cutting throat and then slaughtered by severing the head at its articulation on the occipito-atlantal space. The conventional procedure of flaying was followed. At the time of slaughtering blood was collected in a pail. For complete bleeding thorax of the goat was pressed sufficiently by hands. Then weight of blood was recorded. The slaughtered goats were hoisted by the hocks and the head was removed and weighed. The pelt together with feet was also removed and weighed. The length, width and thickness (at butt, belly and shoulder) of skin were recorded. The full digestive tract was removed and weighed full and empty to get "gut fill" by difference. Liver, kidney, spleen, lung with trachea, heart, caul fat and renal fat were separated from attached tissue and weighed separately. Warm carcass weight was recorded immediately after completing dressing and evisceration.

\section{Results and Discussion}

Effect of dietary energy levels on the feed intake of Black Bengal goats are shown in Table 2. Dry 
matter intake did not vary significantly $(p>0.05)$ among the goats fed different levels of dietary energy. A similar result was obtained by Yagoub et al. (2008) who conducted an experiment with Nubian female goats and fed diets of different energy concentrations.

Table 2. Effect of dietary energy levels on feed intake of Black Bengal goats

\begin{tabular}{lccc}
\hline \multirow{2}{*}{ Parameters } & \multicolumn{3}{c}{ Energy Levels } \\
\cline { 2 - 4 } & Low & Medium & High \\
\hline DM intake $(\mathrm{g} / \mathrm{d})$ & $280.0 \pm 24.2$ & $285.9 \pm 36.2$ & $302.7 \pm 36.4$ \\
Total DM intake $(\mathrm{kg})$ & $33.6 \pm 2.9$ & $34.3 \pm 4.4$ & $38.5 \pm 4.4$ \\
DM intake $(\mathrm{g} / \mathrm{kgBW} /$ day) & 36.6 & 34.8 & 33.7 \\
\hline
\end{tabular}

Values are not significantly different

The influences of different rations with vary energy levels on growth performance of goats : presented in Figure 1, Figure 2 and Figure Average daily live weight gain differ significantly among the goats fed diets different energy levels. Live weight gain of $h$ energy fed goats was significantly $(p<0$. ( higher than that of others.

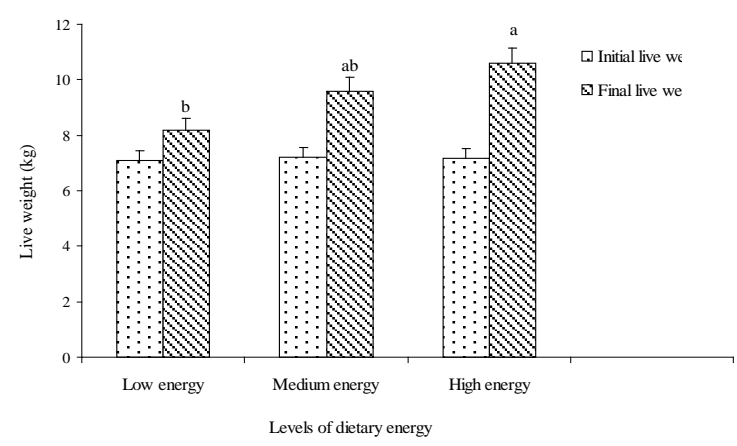

Figure 1. Initial and final live weight at different levels of dietary energy; Bars with different superscripts within the same category differed significantly $(p<0.05)$

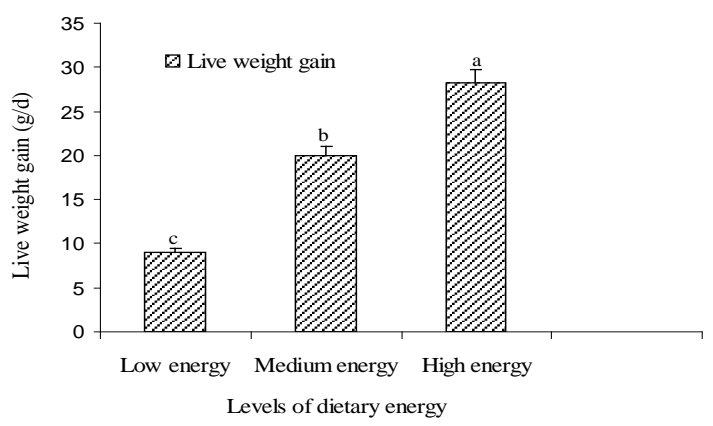

Figure 2. Daily live weight gain of Black Bengal goats at different levels of dietary
A similar result was obtained by Shahjalal et al. (1992) who conducted an experiment with Angora goats fed diets of different energy concentrations. Growth rate of goats increased from 64.0 to $103.5 \mathrm{~g} / \mathrm{d}$ when dietary energy concentration was increased from 10.2 to 11.9 MJ ME/kg DM. Sanjava et al. (1990) and Ibrahim (1996) reported increased rate of gain in male goat kids with an increase of dietary energy level. Decrease of dietary energy level induced a significant $(p<0.001)$ reduction in growth rate, feed conversion efficiency and slaughter weight in Nubian female goat kids (Yagoub et al. 2008). Since the goats in this study were female, their growth rate was lower during this experimental period.

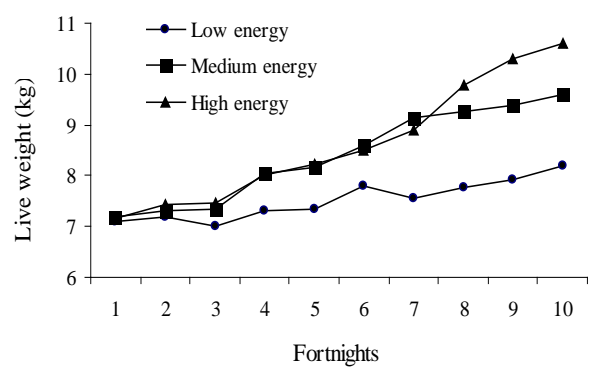

Figure 3. Cumulative live weight of at different levels of dietary energy

Pre-slaughter body measurements of goats raised under three feeding regimes i.e., low, medium, and high energy have been shown in Table 3 . There were significant $(p<0.05)$ differences in body length among different treatment groups. The body length was significantly $(p<0.05)$ higher in high energy group than medium and low energy groups. Moniruzzaman et al. (2002) reported the similar body length (49.5 to 40.5 $\mathrm{cm}$ ) of Black Bengal goats. The body length observed in the present experiment was lower than the findings of Husain (1993) who reported that the body length ranged from 49.3 to 42.2 $\mathrm{cm}$. Bhattacharya et al. (1984) reported $46.5 \pm 0.68 \mathrm{~cm}$ body lengths in $13.14 \pm 0.52 \mathrm{~kg}$ Black Bengal goats. Height at wither, heart girth, circumference of neck and length of neck did not differ significantly among the treatment groups of goats. 
Table 3. Effect of dietary energy levels on preslaughter body measurements of Black Bengal goat

\begin{tabular}{|c|c|c|c|c|}
\hline \multirow{2}{*}{\multicolumn{2}{|c|}{ Parameters }} & \multicolumn{3}{|c|}{ Energy Levels } \\
\hline & & Low & Medium & High \\
\hline \multicolumn{2}{|c|}{ Body length (cm) } & $40.7^{b} \pm 1.5$ & $42.7 \mathrm{ab} \pm 2.1$ & $46.0^{\mathrm{a}} \pm 2.0$ \\
\hline \multicolumn{2}{|c|}{ Height at wither (cm) } & $39.8 \pm 2.3$ & $41.0 \pm 1.8$ & $45.2 \pm 4.01$ \\
\hline \multicolumn{2}{|c|}{ Heart girth $(\mathrm{cm})$} & $46.5 \pm 2.2$ & $48.8 \pm 1.0$ & $49.17 \pm 1.8$ \\
\hline \multirow{3}{*}{$\begin{array}{l}\text { Circumference } \\
\text { of neck }(\mathrm{cm})\end{array}$} & Apex & $18.3 \pm 0.6$ & $19.0 \pm 1.0$ & $20.3 \pm 1.5$ \\
\hline & Middle & $20.3 \pm 0.8$ & $20.3 \pm 0.6$ & $22.0 \pm 1.0$ \\
\hline & Base & $23.3 \pm 2.1$ & $24.5 \pm 1.3$ & $25.0 \pm 1.7$ \\
\hline \multicolumn{2}{|c|}{ Length of neck (cm) } & $14.8 \pm 0.9$ & $16.5 \pm 1.3$ & $16.2 \pm 1.3$ \\
\hline
\end{tabular}

Means with uncommon superscripts at the same row differed significantly $(p<0.05)$

Significant difference $(p<0.05)$ was observed in carcass weight among the goats fed different energy levels (Table 4). Carcass yield was higher in high energy fed goats than others. Yagoub et al. (2008) reported that carcass weight increased with the increase of dietary energy level. There was significant $(p<0.05)$ difference in dressing percentage among different dietary energy levels. Highest dressing percentage $(42.94 \%)$ was obtained in high energy fed goats. The reduction in dressing percentage resulted from the reduction in carcass weight and increase in gut fill in low energy fed goats (Table 4). Dressing percentage increased with the increase of fatness (Preston and Willis 1975) which is associated with feeding of high dietary energy. The dressing percentage was reported to be increased from 45 to $54 \%$ as a result of fattening (Gaili et al. 1972). Ibrahim (1996) reported a significant reduction in dressing percentage of male goats when dietary energy level decreased from 12.0 to $8.0 \mathrm{MJ} / \mathrm{kg}$.

Table 4. Effect of dietary energy levels on carcass yield of Black Bengal goats

\begin{tabular}{llll}
\hline \multirow{2}{*}{ Parameters } & \multicolumn{3}{c}{ Energy Levels } \\
\cline { 2 - 4 } & \multicolumn{1}{c}{ Low } & \multicolumn{1}{c}{ Medium } & \multicolumn{1}{c}{ High } \\
\hline Slaughter weight $(\mathrm{kg})$ & $8.2^{\mathrm{b}} \pm 0.5$ & $9.6^{\mathrm{a}} \pm 1.1$ & $10.6^{\mathrm{a}} \pm 0.9$ \\
Carcass weight $(\mathrm{kg})$ & $3.0^{\mathrm{b}} \pm 0.4$ & $3.9^{\mathrm{a}} \pm 0.7$ & $4.5^{\mathrm{a}} \pm 0.4$ \\
Dressing percentage & $36.3^{\mathrm{b}} \pm 2.6$ & $40.5^{\mathrm{a}} \pm 2.7$ & $42.9^{\mathrm{a}} \pm 2.2$ \\
\hline
\end{tabular}

Means with uncommon superscripts at the same row differed significantly $(p<0.05)$

There were no significant differences in weight of head, heart, spleen, liver, kidney, lung and trachea among the goats of different energy levels (Table 5). The data revealed that weight of gut fill was higher $(p<0.05)$ in low energy fed goats (Table 6). This is probably due to higher dry matter intake of low energy fed goats. This result is in agreement with the report of Yagoub et al. (2008). They observed that gut fill increased significantly $(p<0.05)$ with the decrease of dietary energy level. Non-edible by products such as weight of blood, weight of skin, length of skin, width of skin, thickness of skin, weight of feet, weight of gut and weight of empty gut did not differ significantly among the treatment groups.

Table 5. Effect of dietary energy levels on edible by-products of Black Bengal goats

\begin{tabular}{lccc}
\hline \multirow{2}{*}{ Parameters } & \multicolumn{3}{c}{ Energy Levels } \\
\cline { 2 - 4 } & Low & Medium & High \\
\hline Weight of head $(\mathrm{g})$ & $710.0 \pm 26.5$ & $760.0 \pm 36.1$ & $788.3 \pm 50.1$ \\
Heart $(\mathrm{g})$ & $51.7 \pm 15.3$ & $60.3 \pm 11.2$ & $61.7 \pm 12.6$ \\
Spleen $(\mathrm{g})$ & $34.3 \pm 4.0$ & $33.3 \pm 10.4$ & $44.3 \pm 9.3$ \\
Liver $(\mathrm{g})$ & $376.7 \pm 15.3$ & $386.7 \pm 20.8$ & $388.3 \pm 18.9$ \\
Kidney $(\mathrm{g})$ & $42.7 \pm 2.5$ & $44.3 \pm 21.0$ & $51.7 \pm 10.4$ \\
Lung+Trachea $(\mathrm{g})$ & $171.7 \pm 17.6$ & $173.3 \pm 10.4$ & $169.0 \pm 28.2$ \\
\hline
\end{tabular}

Values are not statistically significant

Table 6. Effect of dietary energy levels on nonedible by-products of Black Bengal goats

\begin{tabular}{|c|c|c|c|c|}
\hline \multirow{2}{*}{\multicolumn{2}{|c|}{ Parameters }} & \multicolumn{3}{|c|}{ Energy Levels } \\
\hline & & Low & Medium & High \\
\hline \multicolumn{2}{|c|}{ Weight of blood (g) } & $400.0 \pm 26.6$ & $413.3 \pm 15.3$ & $460.0 \pm 26.5$ \\
\hline \multicolumn{2}{|c|}{ Weight of skin (g) } & $754.0 \pm 44.1$ & $791.7 \pm 53.5$ & $840.0 \pm 55.7$ \\
\hline \multicolumn{2}{|c|}{ Length of skin (cm) } & $60.0 \pm 3.0$ & $60.3 \pm 1.5$ & $65.0 \pm 4.6$ \\
\hline \multicolumn{2}{|c|}{ Width of skin (cm) } & $51.7 \pm 7.6$ & $52.0 \pm 2.7$ & $53.0 \pm 3.6$ \\
\hline \multirow{3}{*}{$\begin{array}{l}\text { Skin } \\
\text { thickness } \\
(\mathrm{mm})\end{array}$} & Gut & $2.5 \pm 0.1$ & $2.4 \pm 0.2$ & $2.2 \pm 0.2$ \\
\hline & Shoulder & $1.5 \pm 0.1$ & $2.1 \pm 0.5$ & $1.6 \pm 0.4$ \\
\hline & Belly & $1.3 \pm 0.1$ & $1.4 \pm 0.3$ & $1.3 \pm 0.1$ \\
\hline \multicolumn{2}{|c|}{ Weight of feet (g) } & $270.0 \pm 10.0$ & $300.0 \pm 47.7$ & $293.3 \pm 30.1$ \\
\hline \multicolumn{2}{|c|}{ Gut (g) } & $2.6 \pm 0.1$ & $2.5 \pm 0.4$ & $2.5 \pm 0.1$ \\
\hline \multicolumn{2}{|c|}{ Empty gut (g) } & $1.3 \pm 0.1$ & $1.5 \pm 0.4$ & $1.6 \pm 0.2$ \\
\hline \multicolumn{2}{|c|}{ Gut fill $(\mathrm{kg})$} & $1.3^{a} \pm 0.1$ & $1.1^{b} \pm 0.1$ & $0.9 \mathrm{ab} \pm 0.2$ \\
\hline
\end{tabular}

Means with uncommon superscripts at the same row differed significantly $(p<0.05)$

Effect of dietary energy levels on fat deposition is shown in Table 7. Amount of caul fat differed significantly $(p<0.05)$ among the goats fed diets of different energy levels. Weight of caul fat was significantly higher in high energy fed goats than others while the same did not differ between medium and low energy feeding groups. 
Shahjalal et al. (1992) and Ibrahim (1996) reported an increase in carcass fat in goats as the dietary energy level increased. Ash and Norton (1987) reported increased carcass fat in Australian feral goats fed ad libitum compared with those on restricted diet. Renal fat did not differ significantly among the goats fed different levels of dietary energy.

Table 7. Effect of dietary energy levels on fat deposition of Black Bengal goats

\begin{tabular}{lccc}
\hline Parameters & \multicolumn{3}{c}{ Energy Levels } \\
\cline { 2 - 4 } & Low & Medium & High \\
\hline Caul fat $(\mathrm{g})$ & $45.5^{\mathrm{b}} \pm 13.3$ & $63.3^{\mathrm{b}} \pm 20.2$ & $94.5^{\mathrm{a}} \pm 9.1$ \\
Renal fat $(\mathrm{g})$ & $20.0 \pm 5.0$ & $35.3 \pm 15.5$ & $47.3^{2} \pm 15.0$ \\
\hline
\end{tabular}

Means with uncommon superscripts at the same row differed significantly $(p<0.05)$

Percentage of caul fat was significantly $(p<0.05)$ higher in goats fed high energy diets than others (Table 8). Similar results was reported by Yagoub et al. (2008) who conducted an experiment with Nubian female goats fed diets of different energy levels. Percentage of caul fat increased significantly $(p<0.01)$ with the increase of the dietary energy level. Crouse et al. (1978) reported an increase in percentage of caul fat in lambs as the dietary energy level increased. Significantly higher percentage of gut and gut fill were found in low energy received goats than others. A similar result was reported by $\mathrm{Lu}$ and Potchoiba (1990) who conducted an experiment with Alpine and Nubian goats fed diets of different energy concentrations. Percentage of gut fill was higher in goats fed low energy diet than others. Mahgoub et al. (2000) reported significantly $(p<0.001)$ higher percentage of gut fill in Omani lambs fed low energy diet. However, percentage of gut and gut fill did not differ significantly between medium and high energy groups. Percentage of weight of blood, skin, feet, head, heart, lung, liver, spleen, kidney, renal fat and empty gut did not differ significantly among the goats fed different levels of dietary energy.
Table 8. Percentage of different post slaughter body parameters on live weight of Black Bengal goats

\begin{tabular}{lccc}
\hline \multirow{2}{*}{ Body parameters } & \multicolumn{3}{c}{ \% of live weight in different energy levels } \\
\cline { 2 - 4 } & Low & Medium & High \\
\hline Blood & $4.9 \pm 0.4$ & $4.3 \pm 0.4$ & $4.4 \pm 0.4$ \\
Skin & $9.2 \pm 0.4$ & $8.3 \pm 0.8$ & $8.1 \pm 0.4$ \\
Feet & $3.3 \pm 0.1$ & $3.1 \pm 0.3$ & $2.8 \pm 0.1$ \\
Head & $7.7^{2} \pm 1.8$ & $8.0 \pm 0.7$ & $7.6 \pm 0.8$ \\
Heart & $0.6^{2} \pm 0.2$ & $0.5 \pm 0.1$ & $0.6 \pm 0.1$ \\
Lung & $2.1 \pm 0.3$ & $1.8 \pm 0.2$ & $1.6 \pm 0.1$ \\
Liver & $4.6^{2} \pm 0.3$ & $4.1 \pm 0.5$ & $3.8 \pm 0.6$ \\
Spleen & $0.43 \pm 0.1$ & $0.35 \pm 0.1$ & $0.43 \pm 0.1$ \\
Kidney & $0.5 \pm 0.04$ & $0.4 \pm 0.2$ & $0.5 \pm 0.1$ \\
Caul fat & $0.6^{\mathrm{b}} \pm 0.1$ & $0.7^{\mathrm{b}} \pm 0.2$ & $0.9^{\mathrm{a}} \pm 0.1$ \\
Renal fat & $0.2^{2} \pm 0.1$ & $0.4 \pm 0.1$ & $0.5 \pm 0.2$ \\
Gut & $31.4^{\mathrm{a}} \pm 0.7$ & $26.3^{\mathrm{b}} \pm 1.3$ & $24.1^{\mathrm{b}} \pm 2.1$ \\
Empty gut & $16.1 \pm 1.9$ & $14.9 \pm 2.9$ & $15.1 \pm 2.2$ \\
Gut fill & $15.3^{\mathrm{a}} \pm 0.7$ & $10.7^{\mathrm{b}} \pm 0.9$ & $8.9^{\mathrm{b}} \pm 2.1$ \\
\hline
\end{tabular}

Means with uncommon superscripts at the same row differed significantly $(p<0.05)$

Regression analysis of live weight on different body parameters have been shown in Table 9 . The result shows that weight of skin, weight of heart exerts a significant effect on the live weight of goats received high energy diet. Heart weight had a positive relation with the live weight of goats fed medium and low energy diet. Width of skin and weight of gut had a significant positive relation with the live weight of goats fed low energy diet. The individual effects of body length, height at wither, heart girth, neck circumference, weight of carcass, weight of skin, length of skin, width of skin, weight of lung, weight of spleen, weight of liver, weight of kidney, weight of caul fat, weight of gut, weight of empty gut, weight of gut fill on the live weight of goats were not significant in three levels of dietary energy. The result showed that live weight and body length was positively correlated and live weight increased $0.9,1.1$ and $1.3 \mathrm{~kg}$ for each $\mathrm{cm}$ increase of body length in low, medium and high energy received goats. Body length was more associated with live weight in high energy fed goats than others. The regression co-efficient indicated that all the body parameters increased with the increase of live weight. 
Table 9. Regression of live weight on body parameters

\begin{tabular}{|c|c|c|c|c|c|c|}
\hline \multirow{2}{*}{$\begin{array}{l}\text { Body } \\
\text { parameters }\end{array}$} & \multicolumn{2}{|c|}{ Low Energy } & \multicolumn{2}{|c|}{ Medium Energy } & \multicolumn{2}{|c|}{ High Energy } \\
\hline & $\bar{a}$ & $\mathrm{~b}$ & $\mathrm{~b}$ & $b$ & $a$ & $b$ \\
\hline $\begin{array}{l}\text { Body length } \\
(\mathrm{cm})\end{array}$ & 33.2 & 0.9 & 31.82 & 1.1 & 31.9 & 1.3 \\
\hline $\begin{array}{l}\text { Wither height } \\
(\mathrm{cm})\end{array}$ & 32.9 & 0.9 & 30.4 & 1.1 & 30.3 & 1.4 \\
\hline $\begin{array}{l}\text { Heart girth } \\
(\mathrm{cm})\end{array}$ & 23.3 & 2.8 & 40.7 & 0.9 & 29.2 & 1.9 \\
\hline $\begin{array}{l}\text { Circumference } \\
\text { of neck }(\mathrm{cm})\end{array}$ & 6.2 & 1.8 & 13.4 & 0.8 & 9.6 & 1.3 \\
\hline $\begin{array}{l}\text { Carcass } \\
\text { weight }(\mathrm{kg})\end{array}$ & -3.2 & 0.8 & -2.1 & 0.6 & 0.9 & 0.3 \\
\hline $\begin{array}{l}\text { Weight of skin } \\
(\mathrm{kg})\end{array}$ & 195.5 & 68.3 & 574.9 & 22.6 & 191.9 & $61.3^{*}$ \\
\hline $\begin{array}{l}\text { Length of skin } \\
\text { (cm) }\end{array}$ & 24.1 & 4.4 & 47.9 & 1.3 & 54.1 & 1.0 \\
\hline $\begin{array}{l}\text { Width of skin } \\
\text { (cm) }\end{array}$ & 27.9 & $2.4^{*}$ & 44.5 & 0.8 & 44.3 & 0.8 \\
\hline Feet (g) & 122.9 & 17.4 & -5.8 & 31.9 & -48.9 & 32.4 \\
\hline Head (g) & 330.1 & 46.4 & 512.3 & 25.8 & 532.7 & 24.2 \\
\hline Heart (g) & -101.3 & 19.9 & -36.4 & $10.1^{*}$ & -125.8 & $16.8^{*}$ \\
\hline Lung (g) & 156.4 & 1.9 & 138.5 & 3.6 & -151.2 & 30.3 \\
\hline Liver (g) & 30.2 & 9.2 & 316.9 & 7.3 & 331.6 & 5.4 \\
\hline Spleen (g) & 17.2 & 2.1 & -20.9 & 5.6 & -34.2 & 7.4 \\
\hline Kidney (g) & 33.1 & 1.2 & -135.3 & 18.7 & -68.1 & 11.3 \\
\hline Fat (g) & 4.9 & 8.5 & -103.1 & 17.3 & 4.9 & 8.5 \\
\hline Gut (kg) & 0.83 & $0.21^{*}$ & -0.6 & 0.3 & 1.79 & 0.06 \\
\hline Empty gut (kg) & -1.25 & 0.30 & -1.45 & 0.30 & 1.20 & 0.03 \\
\hline Gut fill (kg) & 0.65 & 0.07 & 0.81 & 0.02 & 0.59 & 0.032 \\
\hline
\end{tabular}

$a$, constant; $b$, regression coefficient; *, $p<0.05$

\section{Conclusion}

The results indicated that energy concentration of ration have positive effect on growth and carcass characteristics of Black Bengal goats. The growth rate and carcass gain were higher in high energy fed goats than medium and low energy diet. The present study suggests that adequate energy should be supplied for optimizing growth and carcass parameters in female Black Bengal goats.

\section{References}

Ash AJ, Norton BW (1987). Studies with Australian Cashmere goat. I. Effect of dietary protein concentration and feeding levels on body composition of male and female goats. Australian Journal of Agricultural Research, 38: 971-982.
Banerjee GC (1978). Feeds and Principles of Animal Nutrition. Oxford and IBH Publishing Company, New Delhi, Calcutta.

Bhattacharya R, Ghosh TK, Duttagupta C, Maitra DN (1984). Estimation of body weight in Black Bengal goats from body measurements. Indian Vet. J. 61: 406-408.

Calhoun MC, Lupton CJ, Kuhlmann SW, Baldwin BC (1988). Dietary energy intake and effect on mohair growth. Texas Agricultural Experiment Station Progress Report, Texas A \& M University, P. 53.

Crouse JD, Filed RA, Chant JL, Ferrell CL, Smith GM, Harrison VL (1978). Effect of dietary energy intake on carcass composition and palatability of different weight carcasses from ewe and ram lambs. Journal of Animal Science, 47: 1207-1218.

Devendra C, Burns M (1983). Goat Production in the Tropics. Commonwealth Agricultural Bureaux, Farnham House, Farham Royal, UK.

Devendra C (1988). Nutrition and meat production. In: Goat meat production in Asia. Proc. of workshop held in Tando Jam, Pakistan, 13-19 March, 1988.

FAO (2010). Food and Agricultural Organization of the United Nations. FAOSTAT statistical databases. http://faostat.fao.org.

Gaili ESE, Ghanem YS, Mukhtar AMS (1972). A comparative study of some carcass characteristics of Sudan desert sheep and goats. Animal Production, 14: 351-357.

Husain SS (1993). A study on the productive performance and genetic potentials of Black Bengal goats. PhD Thesis, Department of Animal Breeding and Genetics, Bangladesh Agricultural University, Mymensingh, P. 17-36.

Husain SS, Amin MR, Islam ABMM (1998). Goat Production and its breeding strategy in Bangladesh. Proc. of first national workshop on Animal Breeding, Bangladesh Agricultural University, Mymensingh. 26 November, 1998, P. 17-36.

Ibrahim SE (1996). The effect of dietary energy level on fishing goats. M.Sc. Thesis. University of Khartoum.

Khan J, Wangehuk K, Sampath KT, Poadyal SM, Habib G, Samarasinghe K (2008). Best practices in animal feed production and management in SAARC countries. SAARC Agriculture Centre, Dhaka, Bangladesh. 
Kabir et al. (2014) Bang. J. Anim. Sci. 43 (2): 159- 165

Lu CD, Potchoiba MJ (1990). Feed intake and weight gain of growing goats fed diets of various energy and protein levels. Journal of Animal Science, 68: 1751-1759.

Mahgoub O, Lu CD, Early RJ (2000). Effects of dietary energy density on feed intake, body weight gain and carcass chemical composition of Omani growing lambs. Small Ruminant Research, 37: 35-42.

McGregor BA (1984). Growth, development and carcass composition of goats: a review. Proc. of workshop, University of Queensland, Brisbane, 6-8 February, 1984. Australian Centre for International Agricultural Research, Canberra, Australia. Proc. 7, P. 82-90.

Moniruzzaman M, Hashem MA, Akhter S, Hossain MM (2002). Effect of different feeding systems on carcass and non-carcass parameters of Black Bengal goat. AsianAustralasian Journal of Animal Science, 15: 61-65.

NRC (1981). Nutrient Requirements of Domestic Animals. No.15. Nutrient requirements of Goats, Angora, Dairy and Meat Goats in Temperate and Tropical Countries. National Academy Press, Washington, DC.

Preston TR, Willis MB (1975). Intensive beef production. Pergamon press, Oxford, P. 306-310, 417-418.
Ranjan SK (1980). Animal Nutrition in the Tropics. Vikas Publishing house, Vikas house, Ghajiabod VP, India. P. 163-167.

Sanjava K, Tiwari SP, Narany MP (1990). Effect of plane of nutrient utilization and growth of Goddi Kids. Indian Journal of Animal Nutrition, 7: 7-10.

Shahjalal M, Galbraith H, Topps JH (1992). The effect of changes in dietary protein and energy on growth, body composition and mohair fiber characteristics of British Angora goats. Animal Production, 54: 405 $-412$.

Van der Westhuysen JM, Wentzel D, Grobler MC (1985). Angora goats and mohair in South Africa. NKB printer, 21 De Villers Street, Port Elizabeth, South Africa.

Wilson PN (1958). The effect of plane of nutrition on the growth and development of the East African dwarf goat. I. Effect of plane of nutrition on the live-weight gains and the external measurements of kids. Journal of Agricultural Science, 50: 198-210.

Yagoub YM, Babiker SA (2008). Effect of dietary energy level on growth and carcass characteristics of female goats in Sudan. Livestock Research and Rural Development, 20: 12-17. 